\title{
Impact of COVID-19 on the sale of products and accompanying services to electrical engineering companies in the Czech Republic
}

\author{
Lucie Kaňovská ${ }^{1, *}$, Veronika Bumberová $^{2}$ \\ ${ }^{1}$ Brno University of Technology, Faculty of Business and Management, Czech Republic \\ ${ }^{2}$ Brno University of Technology, Faculty of Business and Management, Czech Republic
}

\begin{abstract}
Research background: The coronavirus pandemic and action taken by companies in response, necessarily led to a significant reduction in the performance of the Czech economy, and especially a downturn in industry. While in sectors it was easy to calculate the slump in production and orders, elsewhere the slowdown in the world economy is expected to be felt in the coming periods. Yet there were also companies that were not significantly affected by the COVID19 situation. One of the options for maintaining a market position may be an emphasis on accompanying services, including smart services which, thanks to the limitations of COVID-19, could significantly alleviate the situation.

Purpose of the article: The purpose of this paper is to find out whether COVID19 will have an impact on the sale of products and accompanying services in the industry selected from the perspective of respondents' perceptions over time.

Methods: This paper draws on a conjunctural research approach via survey and structural interview data collected in electrical engineering companies during the Coronavirus pandemic situation. The data obtained from the quantitative survey carried out in September 2020 is used to evaluate the results by summarizing the answers in the individual variants. The data obtained from qualitative interviews conducted in July 2021 are used both to illustrate the views of selected entrepreneurs from industry who were actively involved in the research, and to map the current situation.

Findings and value added: The results of the quantitative survey show uncertain to more negative views on the impact of sales of firms' own products and services in general, while current qualitative data collection on the present has a positive tendency to perceive further growth and recovery especially in the area of servitization which has helped in crisis resilience.
\end{abstract}

Keywords: COVID-19; electrical engineering companies; sale of products; accompanying services; Czech Republic

JEL Classification: O14; D22; L63; L25

\footnotetext{
*Corresponding author: kanovska@.fbm.vutbr.cz
} 


\section{Introduction}

\subsection{Importance of servitization and digitalization in time of crisis}

Different industry sectors, when it comes to production and innovation, have been touched to varying degrees by digital technology. Regardless, significant parts of production and consumption in all market sectors are affected by digital advances, to the extent a reconsideration of the very nature of industries in terms of their classification has become relevant due to these novel means of creating value. Firms are far more fluid in terms of their industry sector with digitalisation facilitating new or retained value opportunities for customers. Some well-established technological firms are furthermore moving away from the solely technological sector while more traditional businesses make the move the other way.

Servitization is perceived as a process of change, where manufacturing companies intentionally or thanks to the growing fashion introduce elements of services into their business models (Brax and Visintin, 2017). Similarly, servitization is perceived as a transformation process in which a company moves from a product-oriented business model to a service-oriented model (Kowalkowski et al., 2017). Through smart technologies, manufacturing companies can adopt, design, and deliver new, smart, and interconnected products that change the way companies compete and provide services (Porter and Heppelmann, 2014). The role of smart technologies in these serviced manufacturing companies is analyzed by the emerging but rapidly growing literature referred to as digital servitization (Vendrell-Herrero et al., 2017). This term is formally characterized as the provision of smart services embedded in a physical product (Holmström and Partanen, 2014). The use of smart technologies (digital technologies) in servitization is referred to as "smartization" or as "digital servitization" or smart servitization. There is an effort to increase the use of digital components in servitization (Grubic, 2018).

Mobility and face-to-face interaction can diminish in importance when servitization (in a digital sense) and digitalization come together (Rapuccini et al., 2020). Manufacturing businesses are more resilient and flexible to change when they embrace digital processes as regards production and staff skill enhancement (Okorie et al., 2020). Pivoting and cooperation chances gain increased prominence via speeded-up digitalisation of manufacturing, with firms consequently finding it necessary to invest in improving employee digital skills. Business value can also be found through the use of digital technologies in a wide range of areas, from internal process enhancement and greater synergy with suppliers, clients and business partners for realtime data dissemination and cooperation (Soto-Acosta, 2020). Back-end and front-end business processes can be similarly enhanced in many ways via digitalization. B2C and B2B e-commerce websites can be merged with enterprise resource planning (ERP) and warehouse management processes by firms to facilitate automatic order processes (Soto-Acosta, 2020).

Servitization and digitalization can be seen as a means of proactively speeding up and applying the response to the COVID-19 crisis (Rapuccini et al., 2020). This hypothesis was confirmed by the interviews undertaken by Rapuccini et al. (2020): companies who have taken the lead on digitalization and servitization have proved more resilient in this current pandemic situation. Organizations are speeding up their use of digital technology as the optimum means of averting short-term economic disaster during the COVID-19 crisis (Soto-Acosta, 2020). Industrial firms that utilise software-based services alongside other means of digitally enabled service growth could suffer less of an economic hit during a crisis of this nature. (Rapaccini et al., 2020).

It is necessary for businesses to come up with resilience across their operations that allow them to rebuff any type of threat. Strategies must be brought on by industrial companies, including digital product-service offers for customers while retaining their industrial know-how and market position earned over decades of competitive involvement in the engineering sector. Digital servitization can be regarded as a strategic means of analysing how radical alteration and the 
provision of further digital resources, potentially less vulnerable to particular crises, should be brought on and utilised within companies. (Rapaccini et al., 2020).

\subsection{Accompanying services and smart services}

In scientific and professional papers but also in companies, we can come across various terms and definitions related to the services provided for the products of industrial enterprises. Ambiguity can lead to some inaccuracies in determining exactly what specific services are involved and what exactly they mean. This ambiguity in the designation of services of industrial enterprises continues today. In recent years there has been no significant clarification and unification of the terms used among the authors. This paper uses the term "Accompanying Services" and their definition is that "they help to increase the value of the goods sold, facilitate the sale and use of the product, thereby enhancing customer satisfaction". The definition is based on Amico and Zikmund (2001) and LaLonde and Zinser (1976).

Manufacturers offer a variety of accompanying services for their products, from basic to complex, often tailored to customers. Today, services also use smart technologies that make them easier to use for both manufacturers and customers. According to Fischer et al. (2012), the expansion of accompanying service offerings encompasses the following three service categories: 1) customer services, 2) product-related services and 3) services supporting business needs. Two different service modes (basic services and advanced services) can be designated within the second category as product-related services. Basic services enable firms faced with product breakdowns to speedily negotiate them (for example, additional parts, repairs, inspections, and ground-level training). Advanced services help to avert product breakdowns (for example, preventive maintenance processes, process enhancement, training, and maintenance contracts). In place of this last category, which was not included in the questionnaire, two different categories were added: complex solutions and smart services. A complex solution is a product solution which does not require the end user to have to deal with technical issues related to the product as these are all undertaken by the supplier, i.e., regular inspections, service, repairs and ensures the general trouble-free operation of the product. Accompanying services involve the use of smart technologies, also commonly termed smart services, including remote monitoring, remote diagnostics, remote repair, predictive maintenance, etc. Smart services are formed by introducing smart devices into the digital service system (Beverungen et al., 2017).

Services using smart technologies are defined as services tailored for specific customers using data and smart processes (Herman, 2016). A key principle of smart services is a combination of software and hardware technologies that enable the collection of remote performance data and product use to determine their current and predictive status (Grubic and Peppard, 2016). Suppatvech et al. (2019) summarize various ways of using smart technologies in services based on the available literature, such as remote monitoring and reporting of information in real time, monitoring of customer behavior in use, enabling responsive and proactive maintenance, support of optimization and remote control of operations, as well as autonomous management. A field survey of the commercial use of IoT technologies shows that most manufacturers use them to provide basic product-related services, such as time and material repairs and required warranty services (Paiola and Gebauer, 2020).

\section{Research sample and methods}

For the processing of empirical research, sections CZ-NACE 26 (Manufacture of computer, electronic and optical products) and CZ-NACE 27 (Manufacture of electrical equipment) were selected from the classification of economic activities issued by the European Commission. Companies from section CZ-NACE 26, i.e., from electronics and electrical engineering, are subcontractors for many other sectors of the economy, such as the automotive industry and 
mechanical engineering. Part of the section is labor-intensive production and highly productive automated production. Section CZ-NACE 27 belongs to the historically important branches within the manufacturing industry. This section has a very strong position in the Czech economy and offers a wide range of products. The nature of the products of the electrical engineering industry is a prerequisite for the competitiveness of other branches of the manufacturing industry and energy. This division is one of the most important employers in the manufacturing industry (MPO, 2017).

Manufacturers were selected from the faculty database Amadeus. Mostly managers and directors were contacted by email and asked to fill out a questionnaire, which was web-based. We had to exclude 12 answers due to incomplete questionnaires. In total, we were able to continue working and analysing data for 55 fully and correctly completed responses from respondents. Table 1 shows the structure of respondents according to selected characteristics.

Table 1. The structure of respondents according to CZ-NACE

\begin{tabular}{|c|c|c|c|c|}
\hline & Frequency & Percent & $\begin{array}{c}\text { Valid } \\
\text { Percent }\end{array}$ & $\begin{array}{c}\text { Cumulative } \\
\text { Percent }\end{array}$ \\
\hline CZ NACE 26 & 18 & 32.7 & 32.7 & 32.7 \\
\hline CZ NACE 27 & 37 & 67.3 & 67.3 & 100.0 \\
\hline Micro and small enterprises (0-49) & 22 & 40.0 & 50.0 & 50.0 \\
\hline Medium sized enterprises (50-249) & 12 & 21.8 & 27.3 & 77.3 \\
\hline Large enterprises ( $\geq 250)$ & 10 & 18.2 & 22.7 & 100.0 \\
\hline Unknown category (re no. of employees) & 11 & 20.0 & - & - \\
\hline The end-user B2C market & 12 & 21.8 & 21.8 & 21.8 \\
\hline Manufactures or other firms, B2B market & 30 & 54.5 & 54.5 & 76.4 \\
\hline Distributors (distribution channels) & 13 & 23.6 & 23.6 & 100.0 \\
\hline Total & 55 & 100.0 & 100.0 & \\
\hline
\end{tabular}

Source: Kaňovská, Bumberová (2021)

In terms of size, measured by number of employees, there are $40 \%$ micro and small enterprises, $21.8 \%$ medium sized enterprises and $18.2 \%$ large enterprises in the total sample. We had to exclude from the further analysis of mean differences a total of $20 \%$ of respondents in the number unknown category. The predominant customers in terms of profit share are: $21.8 \%$ focused on the B2C market, $54.5 \%$ on the B2B market and $23.6 \%$ focused on distributors.

\subsection{Research strategy and methods}

This paper draws on a mixed research approach via survey and structural interview data collected in electrical engineering companies during the Coronavirus pandemic situation. The data obtained from the quantitative survey carried out in September 2020 was used to evaluate the results by summarizing the answers in the individual variants. Conjunctural research approaches via surveys are based on the opinions of entrepreneurs and managers operating in the field of interest about the future perception through partial questions. The answers do not give a direct quantification but assess the future with more general terms, e.g., better, the same, worse. It was designed so that the company's management could fill it in quickly and operatively.

Originally, a 5-point scale was applied for gathering data from respondents about the negative impact of the COVID-19 situation to sales in each category of product and services provided (1totally agree, 2 - partially agree, 3 - partially disagree, 4 - totally disagree, 5 - without estimate/don't know). We excluded "no answer" due to the absence of business activity for further 
evaluation from respondents. Further, the analysis needed the recoding of the original data into modification (agree and partially agree (1), partially disagree or total disagree (2), without estimate/don't know (3)) for better evaluation of result outputs. For a deeper analysis of differences according to size, field and orientation in the customer market, parametric and nonparametric tests were performed to compare the differences in mean (average score) of the results. However, spider graphs were chosen only to visualize the results.

The survey data was complemented with information from three interviews with executives (CEOs, service directors, managing directors, etc). The data obtained from follow-up qualitative interviews conducted in July 2021 are used both to illustrate the views of selected entrepreneurs from industry who were actively involved in the research. The selection of respondents was subject to intentional, purposeful qualitative sampling where interview participants must be representatives of: 1) all size categories, 2) customer orientation and 3) have to provide comprehensive solutions or include the most defined product-related services. The interviews were aimed at establishing retrospective views on development of sales against answers in the questionnaire and mapping the current situation or tendency. Furthermore, another area of interest was about the role of servitization and smart (advanced) services in times of crisis that are more resilient as suggested in the literature.

\section{Results and discussion}

The following results and discussion are divided into two subsections according to the ongoing stages and forms of the quantitative questionnaire survey and subsequent qualitative interviews. The qualitative survey is taken as a supplement to the survey, which enriches the data with the current development and importance of servitization and advanced services during the coronavirus crisis.

\subsection{Output expectations from questionnaire survey}

Figure 1 shows the total structure of product and service portfolios provided by respondents in a sample. Regarding the results, it can be stated that the more complex and/or technologically based product-related service, the smaller the representation in the portfolio of offers of individual companies. However, it must be said that the offer of a comprehensive portfolio of services is a subject of mostly large companies (that's the one of the reason why they did not indicate product sales only $\mathrm{N}=52$ out of total 55 in a sample) with $60 \%$ proportion of smart solutions/services in portfolio. $83.3 \%$ of medium sized enterprises provide basic services to customers with $50 \%$ representation of product related advanced services, $16.7 \%$ offer comprehensive solutions and $42 \%$ provision of smart services. Micro and small companies as category, is the most hybrid group, comprising $95.5 \%$ of the provision of basic services, $82 \%$ of the provision of advanced services, to a lesser extent a comprehensive solution $36 \%$ and $32 \%$ of respondents mentioned the offer of smart services. In terms of sectors in a sample, CZ-NACE 27 provides more product-related services, including smart services, yet the percentage (approx. $78 \%$ ) of providing advanced services, including the offer of complex solutions (approx. $35 \%$ ), is roughly balanced. 




Figure 1. Product and product-related services provided by respondents

Source: Kaňovská, Bumberová (2021)

The following Table 2 shows descriptive statistics and average scores (mean) including standard deviations of answers. The results of the quantitative survey show the more negative to uncertain perception of respondents in terms of negative impact on sales of products and productrelated services in general. However, the product-related smart services report the only one more positive perception.

Table 2. Total product/service sales negative expectation perceived by respondents in time of crisis

\begin{tabular}{|c|c|c|c|c|c|c|}
\hline $\begin{array}{c}\text { Expectations about } \\
\text { future negative } \\
\text { impact on...... }\end{array}$ & $\begin{array}{c}\mathrm{N} \\
(\%)\end{array}$ & $\begin{array}{c}\text { Agree and } \\
\text { partially } \\
\text { agree } \\
(1)\end{array}$ & $\begin{array}{c}\text { Partially } \\
\text { disagree or } \\
\text { total disagree } \\
(2)\end{array}$ & $\begin{array}{c}\text { Without } \\
\text { estimate/ } \\
\text { don't know } \\
(3)\end{array}$ & $\begin{array}{c}\text { Mean } \\
\text { (average) }\end{array}$ & $\begin{array}{c}\text { Std. } \\
\text { deviation }\end{array}$ \\
\hline Product sales & $\begin{array}{c}52 \\
(94.5)\end{array}$ & $34(61.8)$ & $8(14.5)$ & $10(18.2)$ & 1.5385 & 0.803 \\
\hline $\begin{array}{c}\text { Product-related } \\
\text { basic services }\end{array}$ & $\begin{array}{c}51 \\
(92.7)\end{array}$ & $28(50.9)$ & $13(23.6)$ & $10(18.2)$ & 1.6471 & 0.796 \\
\hline $\begin{array}{c}\text { Product-related } \\
\text { advanced services }\end{array}$ & $\begin{array}{c}41 \\
(74.5)\end{array}$ & $21(38.2)$ & $12(21.8)$ & $8(14.5)$ & 1.6829 & 0.789 \\
\hline $\begin{array}{c}\text { Product-related } \\
\text { complex solution }\end{array}$ & $\begin{array}{c}19 \\
(34.5)\end{array}$ & $12(21.8)$ & $4(7.3)$ & $3(5.5)$ & 1.5263 & 0.772 \\
\hline $\begin{array}{c}\text { Product-related } \\
\text { smart services }\end{array}$ & $\begin{array}{c}22 \\
(40.0)\end{array}$ & $7(12.7)$ & $10(18.2)$ & $5(9.1)$ & 1.9091 & 0.750 \\
\hline
\end{tabular}

Source: Kaňovská, Bumberová (2021)

Further, no statistically significant differences were found for any of the selected characteristics. However, it is clear from the eye-metric test that some areas show slight differences in perception, especially regarding the size of companies and customer orientation. It can be seen from Figure 2 that the tendencies of the development of the negative impact of COVID-19 do not have such an effect on the offer of smart and advanced services (in contrast to other categories), namely in the size category of medium-sized enterprises. Unfortunately, the perception of the negative impact in all categories is most pronounced by micro and small 
companies. The most significant difference in the perception of the negative impact occurs in smart services with an orientation towards the B2B market, where, on the contrary, the development trend is positive (see Figure 3).



Figure 2. Average mean score: negative expectation of product sales according to company size and CZNACE

Source: Kaňovská, Bumberová (2021)

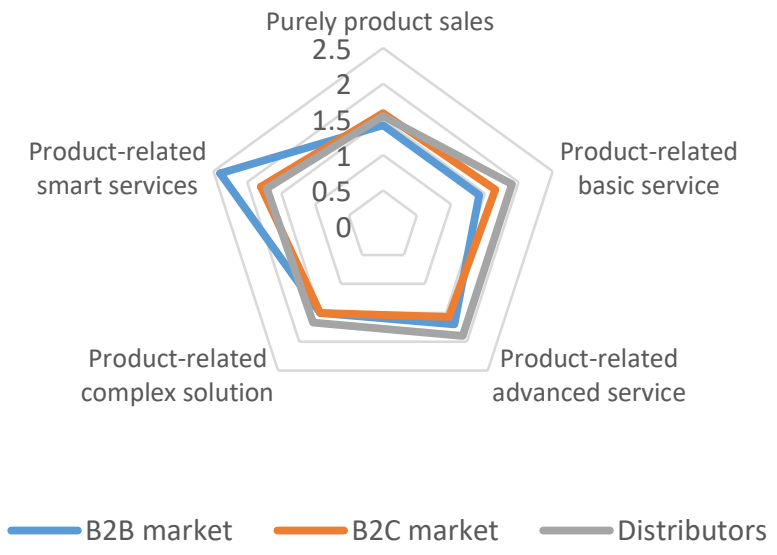

Figure 3. Average mean score: negative expectation of product sales according to customer orientation Source: Kaňovská, Bumberová (2021)

\subsection{Output from the interviews}

The following table No. 3 shows the most important outputs from qualitative interviews with companies from the sample. As for the manufacturer of HW for specific applications (Company 
A), servitization is not common here and its appearance in the company is not dependent on the crisis and does not affect the results, the same applies to smart services. The company that provides remote repair services (Company B) does not perceive the negative or significant impact of Covid as part of its production and does not feel any significant drop in sales. In the last six months, the company has observed an increased interest in smart services as a result of customers thinking about investments and placing more emphasis on maintenance and maximizing the life of technology than in the period before COVID. However, meeting individual requirements for the price of serial products is often not possible. The company (Company C) sees servitization and smart services as a long-term trend, which has further accelerated the process.

Table 3. Summary protocol outputs from interviews

\begin{tabular}{|c|c|c|c|}
\hline Characteristics & Company A & Company B & Company $\mathbf{C}$ \\
\hline Size & Micro enterprise & Small enterprise & Medium enterprise \\
\hline CZ-NACE & CZ-NACE 26 & CZ-NACE 27 & CZ-NACE 26 \\
\hline $\begin{array}{c}\text { Customer } \\
\text { orientation }\end{array}$ & $\mathrm{B} 2 \mathrm{~B}$ & $\mathrm{~B} 2 \mathrm{~B}$ & B2B, B2C \\
\hline $\begin{array}{l}\text { Main business } \\
\text { activity }\end{array}$ & $\begin{array}{l}\text { Manufacturer of HW } \\
\text { (does not primarily } \\
\text { provide accomp. } \\
\text { services) }\end{array}$ & $\begin{array}{l}\text { Manufacturer of SW and HW } \\
\text { (secondary services in the form } \\
\text { of remote repair of their } \\
\text { products) }\end{array}$ & $\begin{array}{c}\text { Manufacturer of SW and } \\
\text { HW } \\
\text { (services are an important } \\
\text { part of the company's } \\
\text { strategy) }\end{array}$ \\
\hline \multicolumn{4}{|c|}{ Questionnaire survey 2020} \\
\hline $\begin{array}{c}\text { Perception of } \\
\text { negative impact on } \\
\text { products and } \\
\text { services }\end{array}$ & $\begin{array}{l}\text { Negative impact on } \\
\text { products and services } \\
\text { excluding smart services } \\
\text { (Average Score: } 1.5 \text { ) }\end{array}$ & $\begin{array}{l}\text { Negative impact on products } \\
\text { and selected services } \\
\text { (Average Score: } 1.3 \text { ) }\end{array}$ & $\begin{array}{l}\text { Negative impact on } \\
\text { products and all services } \\
\text { (Average score: } 1 \text { ) }\end{array}$ \\
\hline \multicolumn{4}{|c|}{ Qualitative interviews 2021} \\
\hline $\begin{array}{l}\text { Retrospective view } \\
\text { on negative impact } \\
\text { on time of crisis }\end{array}$ & $\begin{array}{l}\text { No change in perception } \\
\text { (same impact) }\end{array}$ & $\begin{array}{l}\text { No change in perception } \\
\text { (same impact) }\end{array}$ & $\begin{array}{l}\text { The same impact } \\
\text { perceived only for } \\
\text { products and basic } \\
\text { services (opposite view in } \\
\text { terms of advanced, } \\
\text { complex and smart } \\
\text { services) }\end{array}$ \\
\hline $\begin{array}{l}\text { The change of } \\
\text { perception (reason) }\end{array}$ & - & - & $\begin{array}{l}\text { Existing customers have } \\
\text { made greater use due to } \\
\text { increased market demands }\end{array}$ \\
\hline $\begin{array}{l}\text { Future tendency } \\
\text { (impact perception } \\
\text { with regard to the } \\
\text { prediction of the } \\
\text { forthcoming } 4 \text { th } \\
\text { wave of the crisis) }\end{array}$ & $\begin{array}{l}\text { No perception of } \\
\text { negative impacts }\end{array}$ & $\begin{array}{l}\text { Negative impact only for } \\
\text { products and basic services }\end{array}$ & $\begin{array}{l}\text { Negative impact only for } \\
\text { products and basic } \\
\text { services }\end{array}$ \\
\hline $\begin{array}{l}\text { Perception of } \\
\text { servitization and } \\
\text { smart services as } \\
\text { help in a crisis }\end{array}$ & $\begin{array}{l}\text { Yes, but not for the } \\
\text { activities of purely } \\
\text { specialized HW } \\
\text { manufacturers } \\
\text { (servitization is not } \\
\text { dependent on the crisis, } \\
\text { the same applies to } \\
\text { smart services) }\end{array}$ & $\begin{array}{l}\text { Yes, end customers think more } \\
\text { about investments and place } \\
\text { more emphasis on maintenance } \\
\text { and maximizing the life of } \\
\text { technology than in the period } \\
\text { before COVID (increased } \\
\text { interest in smart services, } \\
\text { remote repairs are not affected } \\
\text { by the crisis or its impact) }\end{array}$ & $\begin{array}{l}\text { Yes, as part of the overall } \\
\text { trend shift, the offer of } \\
\text { complex products/services } \\
\text { on the market (the crisis } \\
\text { accelerated the process) }\end{array}$ \\
\hline
\end{tabular}

Source: Kaňovská, Bumberová (2021)

A common problem faced by manufacturing and the subsequent provision of services is the shortage of and rising prices of almost all production components, various components at different times making production planning difficult and extending delivery times, which has a negative 
impact on sales. However, everyone agrees that the crisis does not and will not have a major impact on the provision of additional, advanced and smart services in the area.

\section{Conclusion}

COVID-19 has clearly marked us all and we will be addressing its impacts in many areas for a long time to come. But what impact did it have on the sales of manufacturing companies and how much did it affect them? The aim of the article was just to find out whether COVID-19 has had an impact on the sale of products and accompanying services in the selected industry. This issue has been monitored over time, after about a year. The results of the quantitative survey show uncertain to more negative views on the impact of sales of firms' own products and services in general, while current qualitative data collection on the present has a positive tendency to perceive further growth and recovery especially in servitization that have helped in crisis resilience. Moreover, everyone agrees that the crisis does not and will not have a major impact on the provision of additional, advanced, and smart services in this area. The contribution of the article was to map the impact of COVID on the sale of products and accompanying services, which is still a new and unexplored area.

\section{References}

1. Amico, M. D., \& Zikmund, W. G. (2001). The power of marketing. Creating and keeping customers in an ecommerce world. Cincinnati: South.

2. Beverungen, D., Matzner, M., \& Janiesch, C. (2017). Information systems for smart services. Information Systems and e-Business Management, 4(15), 781-787.

3. Brax, S. A., \& Visintin, F. (2017). Meta-model of servitization: The integrative profiling approach. Industrial Marketing Management, 60, 17-32.

4. Fischer, T., Gebauer, H., \& Fleisch, E. (2012). Service business development: strategies for value creation in manufacturing firms. Cambridge: Cambridge University Press.

5. Grubic, T. (2018). Remote monitoring technology and servitization: Exploring the relationship. Computers in Industry, 100, 148-158.

6. Grubic, T., \& Peppard, J. (2016). Servitized manufacturing firms competing through remote monitoring technology: an exploratory study. Journal of Manufacturing Technology Management, 27(2), 154-184.

7. Herman, E. (2016). The importance of the manufacturing sector in the Romanian economy. Procedia Technology, 22, 976-983.

8. Holmström, J., \& Partanen, J. (2014). Digital manufacturing-driven transformations of service supply chains for complex products. Supply Chain Management, 19(4), 421-430.

9. Jovanovic, M., Sjödin, D., \& Parida, V. (2021). Co-evolution of platform architecture, platform services, and platform governance: Expanding the platform value of industrial digital platforms. Technovation, Article 102218.

10. Kowalkowski, C., Gebauer, H., Kamp, B., \& Parry, G. (2017). Servitization and deservitization: Overview, concepts, and definitions. Industrial Marketing Management, 60, 4-10.

11. LaLonde, B. J., \& Zinszer, P. H. (1976). Customer service. Meaning and Measurement. The National Council of Physical Distribution Management.

12. MPO, MINISTERVO PRŮMYSLU A OBCHODU (2017, October 30). Zpráva o vývoji malého a středního podnikání a jeho podpoře $v$ roce 2017. https://www.mpo.cz/cz/podnikani/male-a-stredni-podnikani/studie-a-strategicke- 
dokumenty/zprava-o-vyvoji-maleho-a-stredniho-podnikani-a-jeho-podpore-v-roce-2017-241070/ (2017)

13. Okorie, O., Subramoniam, R., Charnley, F., Patsavellas, J., Widdifield, D., \& Salonitis, K. (2020). Manufacturing in the time of COVID-19: An Assessment of Barriers and Enablers. IEEE Engineering Management Review, 48(3), 167-175.

14. Paiola, M., \& Gebauer, H. (2020). Internet of things technologies, digital servitization and business model innovation in BtoB manufacturing firms. Industrial Marketing Management, 89, 245-264.

15. Porter, M. E., \& Heppelmann, J. E. (2014). How smart, connected products are transforming competition. Harvard business review, 92(11), 64-88.

16. Rapaccini, M., Saccani, N., Kowalkowski, C., Paiola, M., \& Adrodegari, F. (2020). Navigating disruptive crises through service-led growth: The impact of COVID-19 on Italian manufacturing firms. Industrial Marketing Management, 88, 225-237.

17. Soto-Acosta, P. (2020). COVID-19 pandemic: Shifting digital transformation to a high-speed gear. Information Systems Management, 37(4), 260-266.

18. Suppatvech, C., Godsell, J., \& Day, S. (2019). The roles of internet of things technology in enabling servitized business models: A systematic literature review. Industrial Marketing Management, 82, 70-86.

19. Vendrell-Herrero, F., Bustinza, O. F., Parry, G., \& Georgantzis, N. (2017). Servitization, digitization and supply chain interdependency. Industrial Marketing Management, 60, 69-81. 